\title{
Mycotoxins in food - how to prevent and what to do when things go bad
}

\author{
Bojan Šarkanj ${ }^{1, *}$, Ivana Dodlek Šarkanj ${ }^{1}$, and Mark Shamtsyan ${ }^{2}$ \\ ${ }^{1}$ University North, Department of Food Technology, Trg dr. Žarka Dolinara 1, 48000, Koprivnica, \\ Croatia \\ ${ }^{2}$ St. Petersburg State Institute of Technology (Technical University), Moskovsky prospect, 26, St. \\ Petersburg, 190013, Russia
}

\begin{abstract}
Mycotoxins are secondary metabolites of microscopic moulds with pronounced toxic properties. Moulds infect products of plant and animal origin at any stage of their receipt, transportation and storage, in industrial and home conditions. Mycotoxins are more commonly found in plant foods. Their biosynthesis by fungi occurs during the ripening and harvesting period under unfavourable meteorological conditions and improper grain storage. Untimely harvesting or insufficient drying of the crop before storage, storage and transportation of products with insufficient protection against moisture leads to the multiplication of microorganisms and the formation of toxic substances in food products.
\end{abstract}

\section{Introduction}

Mycotoxins are secondary metabolites of microscopic moulds with pronounced toxic properties. Moulds infect products of plant and animal origin at any stage of their receipt, transportation and storage, in industrial and home conditions. Mycotoxins are more commonly found in plant foods. Their biosynthesis by fungi occurs during the ripening and harvesting period under unfavourable meteorological conditions and improper grain storage. Untimely harvesting or insufficient drying of the crop before storage, storage and transportation of products with insufficient protection against moisture leads to the multiplication of microorganisms and the formation of toxic substances in food products. Such products and feeds can cause serious diseases for people and animals due to the accumulation of mycotoxins in them, causing mycotoxicosis [1].

Under natural conditions, mycotoxins contaminate cereals, nuts, corn, cocoa beans, spices, fruits, vegetables, sunflower seeds, spices, and farm animal feed. Among several hundreds of known mycotoxins, the most common and posing the greatest threat to human and livestock health are aflatoxins, ochratoxin A, patulin, fumonisins, zearalenone and trichothecene mycotoxins (T-2 toxin, deoxynivalenol, nivalenol). Mycotoxins enter the food chain as a result of mould infestation on crops, both before and after harvest. Most mycotoxins are chemically stable and do not degrade during heat treatment $[1,2]$.

\footnotetext{
*Corresponding author: bsarkanj@unin.hr
} 
Dependent on the ingested concentration mycotoxins in food cause acute toxicity, symptoms of which develop shortly after eating contaminated food; or can have chronic health effects, in particular cancer and immunodeficiency. Of the several hundred mycotoxins known today, about a dozen are the object of the closest attention due to the serious damage they can cause to human health and their frequent presence in food $[1,2]$.

Prevention of mycotoxin contamination can only reduce, but not completely eliminate, the risk of contamination. This is due to the fact that the presence of mycotoxins is influenced by environmental (climatic) conditions that humans cannot influence [1]. However, there are several ways to increase the productivity of plants and reduce stress for them - up to a significant reduction in mycotoxin contamination. These include Good Agricultural Practice (GAP), which is a prerequisite for minimizing mycotoxin contamination of grain, and the implementation of Good Manufacturing Practices (GMP) during the reception, storage, handling and marketing of cereals. To minimize mycotoxin contamination of products, they are divided into measures used before, during and after harvest (Fig 1.). If all measures to reduce the mycotoxin burden fail, and there is a high concentration of mycotoxins in our food, there are additional decontamination options, dilution with healthy food (dependent on the type of mycotoxin and local legislation), biofuel production (usually with increased concentrations of mycotoxins in DDGS), or usage as biomass fuel (for most severe examples).

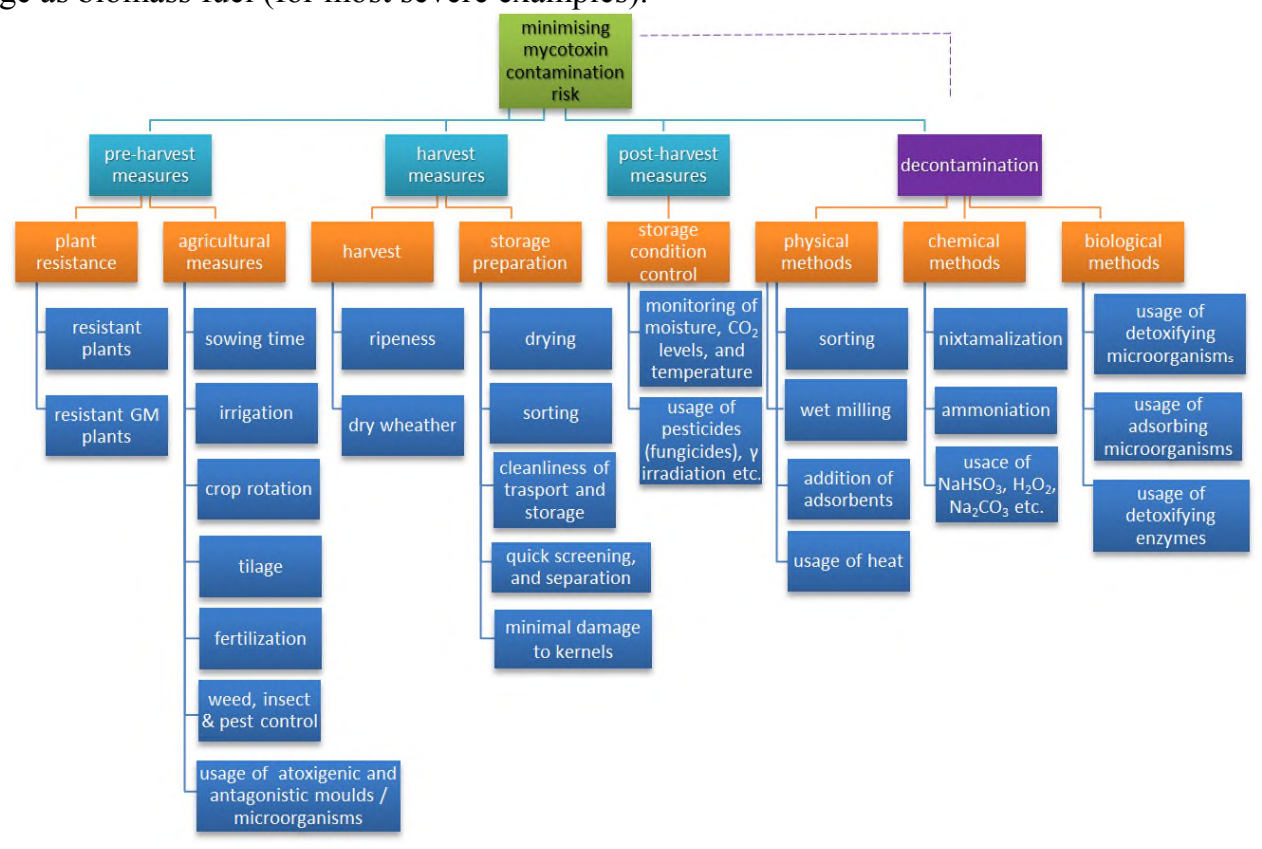

Fig. 1. Techniques for reduction of mycotoxin contamination risk.

\section{Pre-harvest measures}

The pre-harvest mycotoxin control methods include breeding, sowing time, irrigation, correct crop rotation, tillage, control of field infestations of crops with fungi, proper fertilization and weed control.

- Selection

Breeding crops that are resistant or less susceptible to fungal contamination prevents fungal growth and the production of mycotoxins; this approach is the best way to control mycotoxin-producing fungi [1-3]. 


\section{- Sowing time}

Sowing time influences the flowering phase of plants - the earlier the sowing date, the earlier the flowering phase of cereals begins. Mycotoxin contamination is highest when the crop reaches the flowering phase during spore production [4]. This relationship between planting time and reaching different growing stages indicates that the time of planting and maturation of different crops can significantly affect fungal growth and mycotoxin production. For example, when growing maize, earlier planting dates often reduce contamination levels, so unfavourable weather conditions lead to a higher risk of contamination [4]. For wheat and barley, winter varieties develop and mature earlier than spring varieties, thereby increasing the risk of Fusarium contamination of winter varieties. [2]

- Irrigation

Irrigation helps to reduce stress on plants at certain stages of growth, but this method should not be used during flowering and maturation of crops, especially wheat, barley and rye, as excess rainfall - especially during flowering - promotes the spread of Fusarium sp. and contamination of crops.[1]

\section{- Correct crop rotation}

With cropping systems in which maize and wheat are rotated or wheat is planted each year in the same field, the spread of crop disease is increasing. Thus, if crop rotation does not occur, the risk of mycotoxin contamination is higher.

A multi-field crop rotation with alternating rapeseed, sugar beet, sunflower or soybeans can reduce the frequency of mycotoxin contamination [1,2]. Schaafsma et al. (2001) noted that planting crops other than wheat in the two years prior to growing wheat in the study field significantly reduced deoxynivalenol (DON) contamination in the year wheat was grown [5].

Damage to grain by mechanical means, by insects or birds, creates favourable conditions for its infection and damage by fungi, therefore prevention of grain damage is of great importance. In the first year, plants are infected with fungal spores, which can also colonize other plants and spread through the soil. After harvesting maize, stubble remains in the soil, which can be colonized by mushrooms. If maize is grown in the same field next year, subsequent contamination may occur [2].

\section{- Tillage}

To reduce the risk of mycotoxin contamination, it is extremely important to implement proper tillage and control of post-harvest plant waste in the field. For example, ploughing the soil (to a depth of $10-30 \mathrm{~cm}$ ) is more effective in combating mycotoxin contamination than minimal tillage (to a depth of 10-20 cm) and no tillage (seeds are sown in the remains of previous crops). Post-harvest ploughing reduces the growth of $F$. graminearum, which causes red rot on maize cobs (Gibberella stage) and mycotoxin DON contamination. In addition, removing, burning, or ploughing in crop residues can reduce the incidence of fungi infestation on subsequent crops [1,2].

\section{- Proper fertilization}

There is information about the effect of fertilizers on the level of contamination of crops with fungi; this is achieved by altering crop residues, affecting plant growth, and altering the structure and microbial activity of the soil [1].

- Weed, insect \& pest control

Weeds can be infested with a wide range of molds. Any crops, such as wheat, with a lot of weeds will have a high level of contamination [6]. Insects and pest can damage kernels thus enabling easier infection route to the molds.

- Usage of atoxigenic molds and antagonistic molds/microorganisms

The spores of atoxigenic strains of Aspergillus flavus are known to be one of the more successful ways to reduce the aflatoxin burden in maize [7]. 
Several bacteria, yeasts and Filamentous fungi are able to attack Fusarium spp., reduce disease damages and mycotoxin contamination. Some biological agents can antagonize pathogens using multiple mechanisms. Targeted activation of host plant defenses before diseases develop may also serve as biological crop protection strategy in Fusarium management. Multiple postharvest measures also are available.

In recent years, an approach associated with the possibility of limiting harmful pathogens with the help of living microorganisms (bacteria, fungi, and also viruses) and their metabolites has been considered promising. Promising biological agents that can limit the growth of pathogenic fungi and reduce the production of mycotoxins may be useful in protecting crops from mycotoxin contamination. One of the areas of biological control is the use of endophytic microorganisms that live inside plants and increase the resistance of plants to adverse effects.

Biological control could be achieved, not only by direct oppression of the vital activity of the toxin-producing organism, but also due to the successful competition for space and nutrients of the substrate.

As a result of such interactions, not only the growth and development of fungi should be reduced, but also the formation of mycotoxins. The possibility of biological transformation, detoxification or degradation of mycotoxins with the help of microorganisms is a priority area of research, however, the mechanisms of action of biological research agents on toxin fungi that are still inadequate

It is possible to single out several strategies for using microorganisms to reduce pollution with mycotoxins: Processing of plant residues and sowing material, leading to a decrease in the density of populations of fungi - producers of mycotoxins; Processing of plants during the growing season, which suppresses the development of pathogens and activates the mechanisms of self-defence of plants; Post-harvest processing of plant raw materials before storing and processing to prevent further development of fungi. The use of biological methods of control is, definitively attractive, especially from the point of view of ecologicalization of agricultural production.

The ability of bacteria to form compounds of an antibiotic nature determines the effectiveness of their suppression of filamentous fungi. Among such compounds, a complex of lytic enzymes, the most important of which are chitinases, which are involved in the destruction of the cell wall could be used to control the growth of pathogenic fungi. In addition to enzymes, bacteria also form a wide range of antimicrobial metabolites, including peptides and non-peptide components, including polyketides, amino-sugars and phospholipids [8-10]. Strains belonging to different species of Bacillus are recommended as potential agents for suppressing fungi of the genus Fusarium: [8-13].

In laboratory tests, Paenibacillus macerans, Pseudomonas putida, Sporoblomyces roseus, Bacillus subtilis suppressed the growth of $F$. graminearum by $95-100 \%[14,15]$. The use of cultural filtrate of these strains in the field and in greenhouses led to a decrease in fusarium contamination by $21-26 \%[16,17]$.

A significant decrease in the development of fusarium of the barnacle and an increase in the yield of wheat was shown after processing with the strain Streptomyces sp. on the background of artificial inoculation of wheat with F. graminearum [18].

Strains of Bacillus megaterium, isolated from wheat grain, when processing the ears in field conditions, reduced the spread and development of fusarium by 93 and $54 \%$, respectively, and the formation of DON - by $89.3 \%$ [19].

Microorganisms adapted to the environment can provide long-term pressure on pathogenic populations of fungi, successfully restraining their numbers. The chosen strategy for controlling toxin-producing fungi should not only lead to suppression of their growth and development, but also the production of a final product, free-of toxic metabolites. 


\section{Harvest measures}

The harvest has to be planned during full ripeness of the crop during dry wheatear to avoid high humidity necessary for activation of the mycotoxin producing molds [1]. If crops are left in the field longer allowing them to overripe, the contact with insects and pest on the field is prolonged, the outer shell of crops is weakened, and environmental (wheatear) conditions affect them longer, creating better conditions for mycotoxin synthesis (due to longer exposure to daily light), and also for modifications of mycotoxins (binding to sugars, proteins and fats, or incorporating into starch) [1, 20,21].

After cereals have been harvested it is important that they get clean transport to the storage facilities (as elevators, siloes processing factories etc.). During the local transport form field to the nearest storage facility, the transporting time is too short for mycotoxins development but long enough for contamination with mycotoxin producing moulds. If the transport is lasting longer (intercontinental shipment by ships, train or trucks), the transport can also be affecting the total mycotoxin burden. The second important step is clean storage. The crops can be stored in different facilities, most often in siloes. To be able to store the crops for a longer time without affecting their properties, they must be well prepared for the storage. For the cereals, the moisture has to be lowered under 14\%. This will prevent bacterial and fungal growth. If a facility is equipped it is good to perform cleansing and sorting of the crops before storage, so the lower quality (usually used for the feed) is segregated, and crops for food can be screened for mycotoxins. If the concentrations of mycotoxin exceed legal limits in the country where it is put on the market, the crops have to be separated and processed so they meet the required levels. If the legislation allows, the crops can be diluted with unaffected ones, used ad feed (that usually has higher allowed concentrations of mycotoxins), or further processed to remove the affected crops (sorting by color, weight, removing the outer shell, washing/soaking [22]/blanching/malting [23-25], fermenting [26, 27] etc. due to different chemical properties of mycotoxins and different localization within the crop [28]). There is also a possibility of treating crops or storages by antifungal or antimycotoxigenic agents (both synthesized [29-31] and natural [32,33], or in form of nanoparticles [34-37]) to reduce the contamination with mycotoxins. When crops are processed and transported, the precautions need to be taken to minimize the damage and ensure the whole outer (protective) shell that will defend the crop form fungal contamination. Although the presence of molds does not confirm the presence of mycotoxins, and versa, the absence of fungi does not guarantee mycotoxin free product. In the first example, the molds can just start to grow, or it can be atoxigenic species. In the later example moulds can be brushed off, cleaned form crops, or simply stop growing on the crop, but mycotoxin will remain inside product [20].

\section{Post-harvest measures}

The post-harvest measures include control of the storage conditions. The modern siloes have several sensors including temperature, moisture and $\mathrm{CO}_{2}$ sensors which can be used as detectors of fungal growth [38-40]. The mycotoxins are especially prone to heterogeneous (spot) contamination within a bulk material. One nut out of the 10,000 can be contaminated by aflatoxins in such concentration that the whole shipment needs to be discarded if it would be ground, blended and homogeneously processed [41]. The heterogenic distribution is one of the main problems in mycotoxin contamination assessment. To be able to properly assess the mycotoxin contamination, proper sampling has to be performed, usually combining several subsamples (according to the EU commission guide EC 401/2006 if the batch is larger than 50 tones, the sublots needs to be created, and from each sublot 100 
incremental samples per $100 \mathrm{~g}$ need to be combined to a total weight of $10 \mathrm{~kg}$ of the sample) [42]. To ensure the microbial stability of the foods without the usage of thermal methods, gamma irradiation can be used ( $\gamma$-rays) usually up to $10 \mathrm{MeV}$. The food retains its nutritional and organoleptic quality, while it can completely remove mycotoxigenic molds in the range between 3-10 kGy (dose considered as safe by FAO, IAEA and WHO) [43]. Other methods for reducing the growth of molds can also be sued such as fungicides, or sterilization if applicable for the amount of the crop that needs to be stored before processing.

\section{Result and conclusion}

If all of the above-mentioned methods are applied, this still does not guarantee mycotoxin free food. There is always a possibility of heavy contamination due to environmental conditions [44-47], and in that case, the decontamination techniques can be used to reduce mycotoxin burden. The decontamination methods can be divided into: physical, chemical and biological methods. Physical methods include simple processing operation such as screening, fractionation [48], sorting by colour, weight or density [49], wet milling [50-51], the addition of binders and adsorbents (for the feed [52]) and heat [53-56]. Out of chemical methods nixtamalization [57], ammoniation [58], and addition of chemicals that do not pose threat to human, or animal, health (as citric acid, $\mathrm{NaHSO}_{3}, \mathrm{H}_{2} \mathrm{O}_{2}, \mathrm{Na}_{2} \mathrm{CO}_{3} \ldots[56,59]$ ) can be used. The biological methods have shown to be most promising with the usage of live or dead cells (cell wall) of yeast [60] or lactic acid bacteria [61,62] as adsorbing microorganisms. Bound to their cell wall mycotoxins can't be absorbed by the animal that has eaten it. Usage of detoxifying microorganisms such as Trichosporon mycotoxinivorans [63] or bacterial strain BBSH 797 [64] are detoxifying the mycotoxin by degrading the biologically active site of mycotoxins chemical structure (usually epoxide site, carboxylic site, or breaking the mimicry site (e.g. phenylalanine in ochratoxin A [65]). The newest trend is to just extract the detoxifying enzymes instead of whole microorganisms due to their better stability, longer shelf life and easier application [66,67].

If the crops are heavily contaminated so none of the decontamination methods is economically sustainable, the crops can be used in biofuel production (mainly cereals) [68], or as a biofuel in high-temperature furnaces [69]. The main problem if such crops are used in biofuel production is that DDGS afterwards contain even higher concentrations of mycotoxins due to concentration effect (loss of water), and can't be used as feed and an additional source of income for the biofuel producers [70]. The issue with mycotoxins is they are unavoidable natural contaminants of our food, but further research is needed to be able to minimize the mycotoxin burden for both health and economical losses.

\section{References}

1. W.A. Awad, K. Ghareeb, J. Böhm, J. Zentek, Decontamination and detoxification strategies for the Fusarium mycotoxin deoxynivalenol in animal feed and the effectiveness of microbial biodegradation, Food Additives and Contaminants - Part A Chemistry, Analysis, Control, Exposure and Risk Assessment 27, 510-520 (2010)

2. J.P. Jouany, Methods for preventing, decontaminating and minimizing the toxicity of mycotoxins in feeds, Animal Feed Science and Technology 137, 342-362 (2007)

3. I. Hahn, R. Krska, F. Berthiller, Pre- and post-harvest strategies for the prevention, inactivation and detoxification of mycotoxins in food and feed (2015)

4. G.P. Munkvold, Cultural and Genetic Approaches to Managing Mycotoxins in Maize, Annual Review of Phytopathology (2003) 
5. A.W. Schaafsm, L. Tamburic-Ilinic, J.D. Miller, D.C. Hooker, Agronomic considerations for reducing deoxynivalenol in wheat grain, Canadian Journal of Plant Pathology 23, 279-285 (2001)

6. A. Teich, K. Nelson, Survey of Fusarium head blight and possible effects of cultural practices in wheat fields in Lambton County in 1983, Canadian Plant Disease Survey 64, 11-13 (1984)

7. Z. Slavić, T. Dudaš, M. Loc, M. Grahovac, D. Budakov, I. Jajić, S. Krstović, T. Barošević, R. Krska, M. Sulyok, V. Stojšin, M. Petreš, A. Stankov, J. Vukotić, F. Bagi, Biological Control of Aflatoxin in Maize Grown in Serbia, Toxins 12(3), 162 (2020) DOI: 10.3390/toxins12030162

8. S.P. Swanson, C. Helaszek, W.B. Buck et al., The role of intestinal microflora in the metabolism of tricho-thecene mycotoxins, Food Chem. Toxicol. 26, 823-9 (1988) DOI: 10.1016/0278-6915(88)90021-X

9. P. Marten, K. Smalla, G. Berg, Genotypic and phe-notypic differentiation of an antifungal biocontrol strain belonging to Bacillus subtilis, J. Appl. Microbiol. 89, 46371 (2000) DOI: 10.1046/j.1365-2672.2000.01136.x

10. S. Siddiqui, Z.A. Siddiqui, I. Ahmad, Evaluation of fluorescent pseudomonads and Bacillus isolates for the biocontrol of a wilt disease complex of pi-geonpea, W. J. Microb. Biot. 21, 729-32 (2005) DOI: 10.1007/s11274-004-4799-Z

11. C.A. Stockwell, G.C. Bergstrom, W.C. da Luz, Bio-logical control of Fusarium head blight with Bacillus subtilis TrigoCor 1448. In: "National Fusarium Head Blight Forum Proceedings" (University of Kentucky, Lexington, KY. 91-5, 2001)

12. N.I. Khan, D.A. Schisler, M.J. Boehm et al., Field test-ing of antagonists of Fusarium head blight incited by Gibberella zeae, Biol. Control. 29, 245-55 (2004) DOI: 10.1016/S1049-9644(03)00157-9

13. D.A. Schisler, N.I. Khan, M.J. Boehm, P.J. Slinger, Greenhouse and field evaluation of biologi-cal control of Fusarium head blight on durum wheat, Plant Dis. 200, 86, 13506. DOI: 10.1094/ PDIS.2002.86.12.1350

14. N.L.Perondi, W.C. da Luz, R. Thomas, Controle microbiologico da giberela do trigo, Fitopatol. Brasiliera 2, 243-9 (1996)

15. C.A. Stockwell, W.C. Luz, G.C. Bergstrom, Bio-control of wheat scab with microbial antagonists, Phytopathol. 8, 94 (1997)

16. Y. Luo, B. Bleakley, Biological control of Fusarium head blight (FHB) of wheat by Bacillus strains. In: "Proceedings of the 1999 National Fusarium Head Blight Forum" (1999)

17. W.G.D. Fernando, Is there potential for biological control of Fusarium? In: "Proceedings of the 2nd Canadian Workshop on Fusarium Head Blight" (2001)

18. J. Nourozian, H.R. Etebarian, G. Khodakaramian, Biological control of Fusarium graminearum on wheat by antagonistic bacteria, Songklanakarin J. Sci. Technol. 28(1), 29-38 (2006)

19. D. Pan, A. Mionetto, S. Tiscornia, L. Bettucci, Endo-phytic bacteria from wheat grain as bio-control agents of Fusarium graminearum and deoxynivalenol production in wheat, Mycotox. Res. 31(3), 137-43 (2015) DOI: 10.1007/s12550-015-0224-8

20. M. Kovač, D. Šubarić, M. Bulaić, T. Kovač, B. Šarkanj, Yesterday masked, today modified; what do mycotoxins bring next? Archives of Industrial Hygiene and Toxicology 69, 196-214 (2018) DOI: 10.2478/aiht-2018-69-3108 
21. T. Kovač, B. Šarkanj, B. Crevar, M. Kovač, A. Lončarić, I. Strelec, C.N. Ezekiel, M. Sulyok, R. Krska, Aspergillus flavus NRRL 3251 growth, oxidative status, and aflatoxins production ability in vitro under different illumination regimes, Toxins 10(52), 528 (2018) DOI: 10.3390/toxins10120528

22. J. Petrić, B. Šarkanj, I. Mujić, A. Mujić, M. Sulyok, R. Krska, D. Šubarić, S. Jokić, Effect of pretreatments on mycotoxin profiles and levels in dried figs, Archives of Industrial Hygiene and Toxicology 69, 328-333 (2018) DOI: 10.2478/aiht-2018-693147

23. K. Mastanjević, B. Šarkanj, K. Mastanjević, B. Šantek, V. Krstanović, Fusarium culmorum mycotoxin transfer from wheat to malting and brewing products and byproducts, World mycotoxin journal 12(1), 55-66 (2018) DOI: 10.3920/WMJ2018.2340

24. K. Mastanjević, J. Lukinac, M. Jukić, B. Šarkanj, V. Krstanović, K. Mastanjević, Multi-(myco)toxins in malting and brewing by-products, Toxins 11, 30 (2019) DOI: 10.3390/toxins 11010030

25. V. Spanic, Z. Zdunic, G. Drezner, B. Sarkanj, The pressure of Fusarium disease and its relation with mycotoxins in the wheat grain and malt, Toxins 11, 198 (2019) DOI: 10.3390/toxins 11040198

26. W. Qiuping, B. Šarkanj, J. Jurasovic, Y. Chisti, M. Sulyok, J. Gong, S. Sirisansaneeyakul, D. Komes, Evaluation of microbial toxins, trace elements and sensory properties of a high-theabrownins instant Pu-erh tea produced using Aspergillus thbingensis via submerged fermentation, Int. J. Food Sci. Tech. 54, 15411549 (2019) DOI: 10.1111/ijfs.14017

27. K. Mastanjević, B. Šarkanj, R. Krska, M. Sulyok, B. Warth, K. Mastanjević, B. Šantek, B. Krstanović, From malt to wheat beer: A comprehensive multi-toxin screening, transfer assessment and its influence on basic fermentation parameters, Food Chem. 254, 115-121 (2018) DOI: 10.1016/j.foodchem.2018.02.005

28. K. Habschied, B. Šarkanj, T. Klapec, V. Krstanović, Distribution of zearalenone in malted barley fractions dependent on Fusarium graminearum growing conditions, Food Chem. 129, 329-332 (2011) DOI: 10.1016/j.foodchem.2011.04.064

29. B. Šarkanj, M. Molnar, M. Čačić, L. Gille, 4-methyl-7-hydroxycoumarin antifungal and antioxidant activity enhancement by substitution whit thiosemicarbazide and thiazolidinone moieties, Food Chem. 139, 488-495 (2013) DOI: 10.1016/j.foodchem.2013.01.027

30. M. Molnar, V. Pavić, B. Šarkanj, M. Čačić, D. Vuković, J. Klenkar, Mono- and bisdipicolinic acid heterocyclic derivatives - thiosemicarbazides, triazoles, oxadiazoles and thiazolidinones as antifungal and antioxidant agents, Heterocycl. Commun. 23(1), 35-42 (2017) DOI: 10.1515/hc-2016-0078

31. M. Čačić, V. Pavić, M. Molnar, B. Šarkanj, E. Has-Schon, Design and synthesis of some new 1,3,4-thiadiazines with coumarin moieties and their antioxidative and antifungal activity, Molecules 19, 1163-1177 (2014) doi:10.3390/molecules19011163

32. I. Jerković, M. Kranjac, Z. Marijanović, B. Šarkanj, A.M. Cikoš, K. Aladić, S. Pedisić, S. Jokić, Chemical diversity of Codium bursa (Olivi) C. Agardh headspace compounds, volatiles, fatty acids, and insight into its antifungal activity, Molecules 24, 842 (2019) DOI: 10.3390/molecules24050842

33. A.M. Torres, M.L. Ramirez, M. Arroyo, S.N. Chulze, N. Magan, Potential use of antioxidants for control of growth and fumonisin production by Fusarium verticillioides and Fusarium proliferatum on whole maize grain, Int. J. Food Microbiol. 83(3), 319-324 (2003) DOI: 10.1016/S0168-1605(02)00380-X 
34. T. Kovač, B. Šarkanj, I. Borišev, A. Djordjevic, D. Jović, A. Lončarić, J. Babić, A. Jozinović, T. Krska, J. Gangl, C.N. Ezekiel, M. Sulyok, R. Krska, Fullerol C60(OH)24 nanoparticles affect secondary metabolite profile of important foodborne mycotoxigenic fungi in vitro, Toxins 12, 213 (2020) DOI: 10.3390/toxins12040213

35. T. Kovač, I. Borišev, M. Kovač, A. Lončarić, F. Čačić Kenjerić, A. Djordjevic, I. Strelec, C.N. Ezekiel, M. Sulyok, R. Krska, B. Šarkanj, Impact of fullerol C60(OH) 24 nanoparticles on the production of emerging toxins by Aspergillus flavus, Sci. Rep. 10, 725 (2020) DOI: 10.1038/s41598-020-57706-3

36. T. Kovač, B. Šarkanj, T. Klapec, I. Borišev, M. Kovač, A. Nevistić, I. Strelec, Fullerol $\mathrm{C} 60(\mathrm{OH}) 24$ nanoparticles and mycotoxigenic fungi: a preliminary investigation into modulation of mycotoxin production, Environ. Sci. Pollut. Res. 24, 16674-16681 (2017) DOI: 10.1007/s11356-017-9214-z

37. T. Kovač, B. Šarkanj, T. Klapec, I. Borišev, M. Kovač, A. Nevistić, I. Strelec, Antiaflatoxigenic effect of fullerene C60 nanoparticles at environmentally plausible concentrations, AMB Expr. 8, 14 (2018) DOI: 10.1186/s13568-018-0544-0

38. E. Gracia-Cela, E. Kiaitsi, M. Sulyok, A. Medina, N. Magan, Fusarium graminearum in stored wheat: use of $\mathrm{CO} 2$ production to quantify dry matter losses and relate this to relative risk of zearalenone contamination under interacting environmental conditions, Toxins 10(2), 86 (2018) DOI: 10.3390/toxins10020086

39. M.K. Gilbert, A. Medina, M.B. Mack, M.D. Lebar, A. Rodriguez, D. Bhatnagar, N. Magan, G. Obrian, G. Payne, Carbon dioxide mediates the response to temperature and water activity levels in Aspergillus flavus during infection of maize kernels, Toxins 10(1), 5 (2018) DOI: 10.3390/toxins 10010005

40. H.C. Zhai, S.B. Zhang, S.X. Huang, J.P. Cai, Prevention of toxigenic fungal growth in stored grains by carbon dioxide detection, Food Addit. Contam. Part A Chem. Anal. Control Expo. Risk. Assess. 32, 596-603 (2015) DOI: 10.1080/19440049.2014.968221

41. T.W. Kensler, B.D. Roebuck, G.N. Woganm, J.D. Groopman, Aflatoxin: A 50-year odyssey of mechanistic and translational toxicology, Tox. Sci. 120(1), 28-48 (2011) DOI: $10.1093 /$ toxsci/kfq283

42. S. Biselli, C. Persin, M. Syben, Investigation of the distribution of deoxynivalenol and ochratoxin A contamination within a 26 t truckload of wheat kernels, Mycotox. Res. 24, 98-104 (2008) DOI: 10.1007/BF02985287

43. T. Calado, A. Venancio, L. Abrunhosa, Irradiation for mold and mycotoxin control: A review, Compr. Rev. Food Sci. Food Saf. 13(5), 1049-1061 (2014)

44. V. Spanic, Z. Katanic, M. Sulyok, R. Krska, K. Puskas, G. Vida, G. Drezner, B. Šarkanj, Multiple fungal metabolites including mycotoxins in naturally infected and Fusarium - inoculated wheat sample, Microorganisms 8, 578 (2020) DOI: 10.3390/microorganisms 8040578

45. K. Habschied, R. Krska, M. Sulyok, B. Šarkanj, V. Krstanović, A. Lalić, G. Šimić, K. Mastanjević, Screening of various metabolites in six barley varieties grown under natural climatic conditions (2016-2018), Microorganisms 7, 532 (2019) DOI: 10.3390/microorganisms 7110532

46. V. Spanic, M. Viljevac Vuletic, D. Horvat, B. Sarkanj, G. Drezner, Z. Zdunic, Changes in antioxidant system during grain development of wheat (Triticum aestivum L.) and relationship with protein composition under FHB stress, Pathogens 9, 17 (2020) DOI: 10.3390/pathogens9010017

47. H. Houissa, S. Lasram, M. Sulyok, B. Šarkanj, A. Fontana, C. Strub, R. Krska, S. Galindo, A. Ghorbel, Multimycotoxin LC-MS/MS analysis in pearl millet (Pennisetum 
glaucum) from Tunisia, Food Control 106, 106738 (2019) DOI: 10.1016/j.foodcont.2019.106738

48. J.W. Dorner, Management and prevention of mycotoxins in peanuts, Food Addit. Contam. Part A Chem. Anal. Control Expo. Risk. Assess. 25(2), 203-208 (2008) DOI: 10.1080/02652030701658357

49. M. Aoun, W. Stafstrom, P. Priest, J. Fuchs, G.L. Windham, W.P. Williams, R.J. Nelson, Low-cost grain sorting technologies to reduce mycotoxin contamination in maize and groundnut, Food Control 118, 107363 (2020) DOI: 10.1016/j.foodcont.2020.107363

50. J. Park, D.H. Kim, J.Y. Moon, J.A. An, Y.W. Kim, S.H. Chung, C. Lee, Distribution Analysis of Twelve Mycotoxins in Corn and Corn-Derived Products by LC-MS/MS to Evaluate the Carry-Over Ratio during Wet-Milling, Toxins 10(3), 319 (2018) DOI: 10.3390/toxins 10080319

51. S. Schaarschmidt, C. Fauhl-Hassek, The fate of mycotoxins during the primary food processing of maize, Food Control 121, 107651 (2021) DOI: 10.1016/j.foodcont.2020.107651

52. A. Huwig, S. Freimund, O. Käppeli, H. Dutler, Mycotoxin detoxication of animal feed by different adsorbents, Tox. Lett. 122(2), 179-188 (2001) DOI: 10.1016/S03784274(01)00360-5

53. C.N. Ezekiel, M. Sulyok, I.M. Ogara, W.A. Abia, B. Warth, B. Šarkanj, P. Turner, R. Krska, Mycotoxins in uncooked and plate-ready household food from rural northern Nigeria, Food Chem. Tox. 128, 171-179 (2019) DOI: 10.1016/j.fct.2019.04.002

54. W.A. Abia, B. Warth, C.N. Ezekiel, B. Sarkanj, C.P. Turner, D. Marko, R. Krska, M. Sulyok, Uncommon toxic microbial metabolite patterns in traditionally homeprocessed maize dish (fufu) consumed in rural Cameroon, Food Chem. Tox. 107, 1019 (2017) DOI: 10.1016/j.fct.2017.06.011

55. C.A. Okeke, C.N. Ezekiel, M. Sulyok, O.R. Ogunremi, C.O. Ezeamagu, B. Šarkanj, B, Warth, R. Krska, Traditional processing impacts mycotoxin levels and nutritional value of ogi - A maize-based complementary food, Food Control. 86, 224-233 (2018) DOI: 10.1016/j.foodcont.2017.11.021

56. S. Generotti, M. Cirlini, B. Šarkanj, M. Sulyok, F. Berthiller, C. Dall'Asta, M. Suman, Formulation and processing factors affecting trichotecene mycotoxins within industrial biscuid-making, Food Chem. 229, 597-603 (2017) DOI: 10.1016/j.foodchem.2017.02.115

57. S. Schaarschmidt, C. Fauhl-Hassek, Mycotoxins during the Processes of Nixtamalization and Tortilla Production, Toxins 11(4), 227 (2019) DOI: 10.3390/toxins 11040227

58. D.L. Park, L.S. Lee, R.L. Price, A.E. Pohland, Review of the Decontamination of Aflatoxins by Ammoniation: Current Status and Regulation, J. Assoc. Off. Anal. Chem. 71(4), 685-703 (1988) DOI: 10.1093/jaoac/71.4.685

59. G. Kaushik, Effect of processing on mycotoxin content in grains, Crit Rev Food Sci Nutr. 55, 1672-1683 (2015) DOI: 10.1080/10408398.2012.701254

60. J.P. Jouany, A. Yiannikouris, G. Bertin, The chemical bonds between mycotoxins and cell wall components of Saccharomyces cerevisiae have been identified, Arch. Zootechnica 8, 26-50 (2005)

61. B.J. Muhiakdin, N. Saari, A.S.M. Hussin, Review on the Biological Detoxification of Mycotoxins Using Lactic Acid Bacteria to Enhance the Sustainability of Foods Supply, Molecules 25(11), 2655 (2020) DOI: 10.3390/molecules25112655 
62. N. Wang, W. Wu, J. Pan, M. Long, Detoxification Strategies for Zearalenone Using Microorganisms: A Review, Microorganisms 7(7), 208 (2019) DOI: 10.3390/microorganisms 7070208

63. O. Molnar, G. Schatzmayr, E. Fuchs, H. Prillinger, Trichosporon mycotoxinivorans sp. nov., A New Yeast Species Useful in Biological Detoxification of Various Mycotoxins, Syst. Appl. Microbiol. 27(6), 661-671 (2004) DOI: 10.1078/0723202042369947

64. E. Fuchs, E.M. Binder, D. Heidler, R. Krska, Structural characterization of metabolites after the microbial degradation of type A trichothecenes by the bacterial strain BBSH 797, Food Addit. Contam. Part A Chem. Anal. Control Expo. Risk. Assess. 19(4), 379386 (2002) DOI: 10.1080/02652030110091154

65. T. Klapec, B. Šarkanj, I. Banjari, I. Strelec, Urinary ochratoxin A and ochratoxin alpha in pregnant women, Food Chem. Tox. 50, 4487-4492 (2012) DOI: 10.1016/j.fct.2012.09.030

66. B. Grenier, H.E. Schwartz-Zimmermann, C. Gruber-Dorninger, I. Dohnal, M. Aleschko, G. Schatzmayr, W.D. Moll, T.J. Applegate, Enzymatic hydrolysis of fumonisins in the gastrointestinal tract of broiler chickens, Poult Sci. 96(12), 43424351 (2017) DOI: 10.3382/ps/pex280

67. F.B. Taheur, B. Kouidhi, Y.M.A. Al Qurashi, J.B. Salah-Abbes, K. Chaieb, Review: Biotechnology of mycotoxins detoxification using microorganisms and enzymes. Toxicon 160, 12-22 (2019) DOI: 10.1016/j.toxicon.2019.02.001

68. F. Wu, G.P. Munkvold, Mycotoxins in Ethanol Co-products: Modeling Economic Impacts on the Livestock Industry and Management Strategies, J. Agric. Food Chem. 56(11), 3900-3911 (2008) DOI: 10.1021/jf072697e

69. G.C. Shurson, The Role of Biofuels Coproducts in Feeding the World Sustainably, Annu Rev Anim Biosci. 5, 229-254 (2017) DOI: annurev-animal-022516-022907

70. R. Krska, M. de Nijs, O. McNerney, M. Pichler, J. Gilbert, S. Edwards, M. Suman, N. Magan, V. Rossi, H.J. van der Fels-Klerx, F. Bagi, B. Poschmaier, M. Sulyok, F. Berthiller, H.P. van Egmond, Safe food and feed through an integrated toolbox for mycotoxin management: the MyToolBox approach, World Mycotoxin J. 9(4), 487-495 (2016) DOI: 10.3920/WMJ2016.2136 